\title{
Impact of Mobile Marketing on Customer Loyalty in Jordan
}

Sulieman Al-Hawary, Ahmad Obiadat

Al al-Bayt University

Jordan

\{dr_sliman@yahoo.com\}\{ahmad.obdt@gmail.com\}

ABSTRACT: This study aimed to identify the impact of mobile marketing on the customer's loyalty in Jordan. The dimensions of mobile marketing were (Interactivity, Personalization, Localization, and Convenience). The study population consisted of the customers shopping through mobile in Jordan, a sample of 403 customers were taken. Their responses were investigated using a questionnaire designed for this purpose. The results were collected, entered into the computer and tested the hypotheses using the SPSS program.

The study results showed a statistically significant effect of Mobile Marketing (Interactivity, Personalization, and Convenience) on Customers' Loyalty, and there is a statistically insignificant effect of Localization on Customers' Loyalty. based on the results, the researchers came up with some recommendations related to the fields of mobile content design, sharing information, benefit from the experiences, and solving customers problems.

Keywords: Mobile, Marketing, Customer, Loyalty, Jordan

Received: 26 July 2019, Revised 10 October 2019, Accepted 19 October 2019

(C) 2019 DLINE. All Rights Reserved

DOI: $10.6025 / \mathrm{ijwa} / 2019 / 11 / 4 / 136-151$

\section{Introduction}

Nowadays, in the context of global economic crises and the information revolution, organizations in general and marketing, in particular, are witnessing some challenges posed by the current business environment, regardless of the opportunities, these challenges may lead these organizations to exit the market. It poses an urgent problem for the marketing function and therefore calls for the recruitment of different marketing methods and practices to address this, and the development of this issue itself is a significant indication of the importance of marketing and the need for it. However, this concern is increasingly evident through the ways of dealing, confronting and addressing these marketing challenges, which may play a role in marketing to solve the problems of the organization, This leads us that marketing is essential to influence consumers' impulsive purchasing behavior, and due to the fast development of both electronic and mobile commerce new ways of advertising have emerged (Bucht and Gillberg, 2015).

Marketing to customers has become increasingly challenging, this is due to that markets are constantly changing and accelerating, and are still changing fast, and new markets are rising persistently. Also correspondence channels about services, products 
and data are changing at a progressive pace.

Mobile phone is not only a modern communication tool but also an essential mean of marketing of products, services and ideas provided by organizations, whether small or large, by sending short messages about their services and products to their customers via their mobile phones. People are most receptive to mobile marketing in all its kinds like - based on location-, advertising via MMS, SMS and branded apps.

As a result, mobile marketing has become an important opportunity, it is a relatively new marketing technology, so organizations and institutions are finding that mobile marketing is very necessary because the mobile phone itself is a very direct mean to reach thousands and even millions of customers wherever they are in just a few seconds (Richardson, 2010 ). In marketing, the advantages of mobile devices, including smartphones, are technological improvements that have led to the creation of various functions (including media, Internet, camera, SMS etc.) all in one small device, as well as the traditional role of phone call(Schierholz, 2007).

Organizations make efforts to retain customers and increase their loyalty; this stems from the fact that the cost of the retention of one client is five times the cost of maintaining a Customer (Dowling, 2012). Organizations that have market-oriented vision have considered existing customers are the centre of the organization and work hard to retain them, increase their loyalty and reduce their loss. The key to maintaining the customer is to provide them with new ways to communicate and respond quickly, communicate with them and meet their needs and desires. Hence there are growing numbers of new customers and companies competing among themselves to get them.

The success of organizations in general depends on the organization's ability to build a solid base of loyal customers, especially as these customers are often a source of attracting new customers through their opinions, recommendations and positive suggestions that must be affected by new or potential Customers, meeting customers' demands and increased interaction and communication lead to satisfying their desires, thus increasing their satisfaction. This is an important factor in forming customer loyalty to the organisation (Hallowell,1996).

This paper focused on a new trend in marketing communications. Mobile marketing, being a part of communication technologies which have penetrated markets throughout the world, mobile marketing is likely to have a strong influence on customer's loyalty, and It should be noted there is not much research done in this area. The importance of this study stemmed from the importance of the role played by mobile phone in marketing in the face of the fierce competition in the global market, which requires the attention of those responsible for trade and marketing using digital marketing in general and using phone platforms, in particular, to support them and enable them to compete for its effective and inexpensive way. Therefore, this study would be a deliberate attempt to benefit from the accumulated knowledge available from researchers efforts in this area and reveal the nature of the relationships between the variables. This study aimed to give an overview of mobile marketing effect on customer loyalty by the ways that organizations followed for mobile marketing.

\section{Theoritical Framwork and Hypotheses Development}

\subsection{Mobile Marketing}

Mobile Marketing is a medium that allows business organizations to interact with their customers in a personalized manner (Gana and Koce, 2016 ), These include mobile web, mobile applications, mobile advertising, SMS (short message service) and MMS (multimedia message services). A mobile phone is a modern gadget. Today's mobile phones can act as clocks, alarms MP3 players, cameras, video recorders, calendars, notebooks, messaging devices, and they can make voice calls. Mobile phone is a small device that has had a huge effect on our daily lives, and it is no longer just a way to communicate with others, althoughit has just profoundly affected the way we communicate and behave daily.

Mobile use has increased dramatically during the recent years. One of the reasons is that telecom operators, keep on adding new services and features to encourage further mobile adoption (Bauer et al., 2005), similarly, phones manufacturers. According to the International Telecommunications Union, currently, mobile broadband networks cover $84 \%$ of the world's population (ITU, 2016). Five of every seven people in the world use a mobile phone - that's five billion people (GSMA Intelligence, 2017), and the number of smartphone users is forecast to reach 4.77 billion $^{(1)}$. That shows the popularity of smartphone ownership in the whole world. Smartphones became the most popular devices to access the internet. 


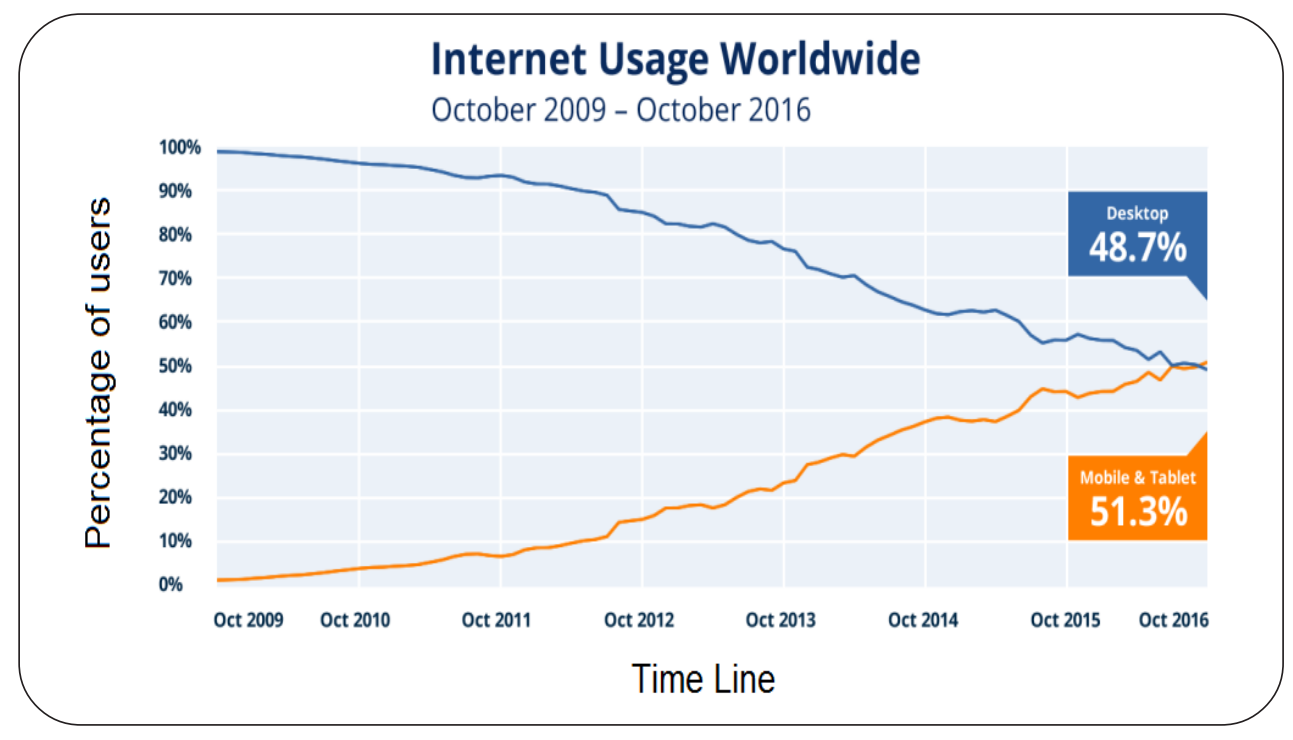

Figure 1. Internet usage worldwide

\section{Source: Statistic Database ${ }^{(1)}$}

In Jordan the number of mobile phone subscribers reached 14 million approximately in $2015^{(2)}$, this number exceeded the population of Jordan. The use of broadband mobile Internet in Jordan is growing as users rely more on the internet. It should be noted that the estimated the penetration rate of smartphone in Jordan is $80 \%{ }^{(3)}$ of the total number of mobile phones, Moreover, according to Tim Bajarin, a technology columnist and principal analyst at creative strategies, all mobile phones selling would be 'smartphones' by 2018 (Fiegerman, 2011), and mobile marketing is expected to be the biggest advertising platform by 2020 exceeding TV and internet by reach, engagement and advertisement revenue (Waele, 2010). This is due tothe spread and expansion of 3G, 4G networks and competition between companies as the changing needs of users towards greater reliance on the mobile Internet have contributed to increasing the penetration of these phones which provide traditional telecommunications services and mobile Internet services. Mobile phone in marketing provides new ways to the market and has become used in the follow-up and termination of private business.

\subsubsection{Mobile Marketing Concept}

Mobile marketing, also can be called wireless marketing, which offers companies a powerful marketing potential via direct communication with customers, anytime and anywhere (Dickinger and Murphy, 2004), The unique characteristics of the mobile channel (high response rate, available at anytime and anyplace, comparatively low Price) and the technology savvy generation, compel marketers to consider mobile along with other options in the process of the marketing communication mix selection. Moreover, the mobile channel should be considered in an integrated manner along with traditional communication channels and not just a substitute for traditional channels. (Mirbagheri and Hejazinia 2010).

The mobile marketing institute defines 'mobile Marketing' as using wireless media to send a written message and to receive a direct reply in a marketing communication program (Ghaleno et al., 2016). According to the Mobile Marketing Association (MMA, 2009), the new definition of mobile marketing is "a set of practices that enables organizations to communicate and engage with their audience interactively and relevantly through any mobile device or network", also Rohm et al., (2012) defines mobile marketing as organizations', companies', and brands' efforts to promote, inform, sell, or otherwise drive consumers to take some action using a mobile platform .

\footnotetext{
${ }^{1}$ Source: Statista Database at: https://www.statista.com/statistics/274774/forecast-of-mobile-phone-users-worldwide

${ }^{2}$ Source: Statista Database at: https://www.statista.com/statistics/273018/number-of-internet-users-worldwide

${ }^{2}$ Department of Statistics 2016, Amman, Jordan

${ }^{3}$ Addustour Newspaper, Amman, No. $1805327^{\text {th }}$ October, 2017.
}

138 International Journal of Web Applications Volume 11 Number 4 December 2019




\begin{tabular}{|l|l|}
\hline Author & Definition \\
\hline Polyzos, (2002) & $\begin{array}{l}\text { All the activities required to communicate with the Customer through the use } \\
\text { of mobile devices to promote the selling of products or services and the } \\
\text { provision of information about these products and services. }\end{array}$ \\
\hline Dickinger et al., (2005) & $\begin{array}{l}\text { Using interactive wireless media to provide Customers with time and location } \\
\text { sensitive, personalised information that promotes goods, services and ideas, } \\
\text { thereby generating value for all stakeholders. }\end{array}$ \\
\hline Haghirian and Inoue, (2005) & $\begin{array}{l}\text { The usage of mobile internet-based media to transmit advertising messages } \\
\text { to consumers, irrelevant of time and location, with personalised information } \\
\text { with the overall goal to promote goods and services. }\end{array}$ \\
\hline Shankar and Balasubramanian, (2009) & $\begin{array}{l}\text { As the two-way or multi-way communication and promotion of an offer be- } \\
\text { tween a firm and its customers using a mobile medium, device, or technology. }\end{array}$ \\
\hline Huang and Symonds, (2009) & $\begin{array}{l}\text { The process of delivering messages from business to consumers using per- } \\
\text { mission-based and interactive communication services over mobile commu- } \\
\text { nication media }\end{array}$ \\
\hline Pousttchi and Wiedeman,(2010) & $\begin{array}{l}\text { The use of wireless media as an integrated content delivery and direct re- } \\
\text { sponse vehicle within a cross-media or stand-alone marketing communica- } \\
\text { tions program. }\end{array}$ \\
\hline Kaplan,(2012) & $\begin{array}{l}\text { Any marketing activity conducted through a ubiquitous network to which } \\
\text { consumers are constantly connected using the personal mobile device. }\end{array}$ \\
\hline
\end{tabular}

Table 1. Mobile Marketing definitions

\subsubsection{Mobile Marketing Dimensions}

Previous studies have addressed mobile marketing Dimensions from different perspectives. As the table below shows a set of mobile marketing Dimensions covered by previous studies

\begin{tabular}{|l|l|}
\hline Smutkupt et al., 2010 & Interactivity, Ubiquity, Personalization, Localization, Industry Background. \\
\hline Bauer et al., 2005 & Interactivity, Ubiquity, Personalization, Localization, \\
\hline Holland, 2010 & Interactivity, Ubiquity, Personalization, Location sensitivity, Immediacy. \\
\hline Efraim and David, 2002 & Convenience, Ubiquity, Personalization, Localization, Instant connectivity \\
\hline Michael and David, 2003 & Convenience, Ubiquity, Personalization, Localization, Accessibility. \\
\hline Zeng et al., 2003 & Convenience, Ubiquity, Personalization, Localization, Accessibility. \\
\hline $\begin{array}{l}\text { Basic characteristics of } \\
\text { Mobile Marketing }\end{array}$ & Interactivity, Ubiquity, Personalization, Localization, Industry Background, Convenience. \\
\hline
\end{tabular}

Table 2. Summary of mobile marketing Dimensions 
Based on the above, the study addressed the mobile marketing Dimensions that affect customer loyalty, in proportion with the study population where they were relying on four dimensions as follows:

Interactivity: Interactivity is regarded as an important characteristic of marketing and has been studied extensively over the last decade and generally believed to be a multidimensional construct (Gao et al., 2009), most previous studies have agreed that there are three major components in the exchange of communication between various parties, user control, two-way communication, and synchronicity (Hsiao, 2015).

\begin{tabular}{|l|l|}
\hline Liu and Shrum, (2002) & $\begin{array}{l}\text { The degree to which two or more communication parties can act on each other on the } \\
\text { communication media, and on the messages and the degree to which such influences } \\
\text { are synchronised. }\end{array}$ \\
\hline Raney et al., 2003) & $\begin{array}{l}\text { The extent to which users can participate in modifying the form and content of a } \\
\text { mediated environment in real time. }\end{array}$ \\
\hline Kellher (2009) & $\begin{array}{l}\text { Capability to assist bi-directional communication between the companies and their } \\
\text { public. }\end{array}$ \\
\hline Laudon and Laudon 2014 & Two-way communication between a merchant and consumer. \\
\hline
\end{tabular}

Table 3. Definitions of the dimension "Interactivity" from previous studies

Localization: Mobile devices have GPS capabilities to identify their physical location. Also, this feature provides marketers with the opportunity to target location sensitive promotional offers to mobile device users (Shankar and Balasubramanian, 2009), and consumers increasingly expect tailored and location-based services, reinforce the importance of location and time, and personalization in mobile marketing, (Watson et al., 2000).

\begin{tabular}{|l|l|}
\hline Clarke,(2001) & Ability to identify the geographical position of a mobile user by locating the mobile device. \\
\hline Al-qatan, (2011) & $\begin{array}{l}\text { Ability to provide the product or services to potential customers depending on their current } \\
\text { location by using positioning technologies Such as the Global Positioning System (GPS) that } \\
\text { provides reliable information's at time and location }\end{array}$ \\
\hline
\end{tabular}

Table 4. Definitions of the dimension "Localization" from previous studies

Personalization: Previous studies have found that personalised service can solve the problem of information overload (Liang and $\mathrm{Ku}, 2006$ ) and make the information more useful to users because the mobile is a very personal device, seldom employed by anyone except its owner, It is also equipped with a SIM (subscriber identification module) card that can store personal information and identity (Junglas and Watson, 2003). For teenagers, a mobile phone is used as a means of self-expression, as its features (e.g., ringtone, display), are personalised to reflect the preferences of its user (Walsh and White, 2007). For adults, the mobile medium becomes more personal when it contains important information, such as contacts and messages (Bauer et al., 2005).

\begin{tabular}{|l|l|}
\hline Holland, (2010) & $\begin{array}{l}\text { Messages can be targeted to individual consumers based on their interests, needs, prefer } \\
\text { ences (location in time), unlike communication through other media, mobile phones are } \\
\text { personal not shared. }\end{array}$ \\
\hline Smutkupt, (2010) & $\begin{array}{l}\text { The mobile phone is highly personal, rarely used by anyone except its owner,Itis also } \\
\text { equipped with a SIM (subscriber identification module) card that can store personal infor- } \\
\text { mation and identity. }\end{array}$ \\
\hline
\end{tabular}

Table 5. Definitions of the dimension "Personalization" from previous studies

140 International Journal of Web Applications Volume 11 Number 4 December 2019


Convenience: is a key advantage for customers who use their mobile device to complete a broad range of activities in a more comfortable way through the use of certain mobile marketing services that allow consumers now access detailed information about products or services at the point of sale, allowing for a better purchasing decision to be made at the moment (Mort and Drennan, 2002).

Consumers derive utilitarian value from efficient and timely service delivery in general (Childers et al. 2001), This argument holds specifically for mobile devices, which enable consumers to collect information and conduct transactions at any time and place (Balasubramanian et al., 2002).

\begin{tabular}{|l|l|}
\hline Xu and Gutiérrez, (2006) & $\begin{array}{l}\text { Powerful and small-sized mobile terminals offer users an opportunity to use the right services any } \\
\text { where at any time compared to another means. }\end{array}$ \\
\hline Al-qatan, (2011) & $\begin{array}{l}\text { Size and usability are attributes that made the mobile devices more convincement ways than tradi } \\
\text { tional computers as well as the ability to connect to the internet easily and quickly. }\end{array}$ \\
\hline
\end{tabular}

Table 6. Definitions of the dimension "Convenience" from previous studies

\subsection{Customer Loyalty}

In today's competing world, customers are the main centre of attention of the companies, and their loyalty is the main factor of acquiring the competitive benefit of the organizations.

In the recent years, various economic institutions, from small newly founded companies to supranational companies, have realized the importance of customer's loyalty. (Mostaghimi et al., 2016). Managers have since realized that retaining a customer costs less than it costs to entice new customer, and that is why client retention has become a foundation stone in marketing, this is what indicates to customer loyalty is a very vital component of any successful business (Coyles and Gokey, 2005).

The success of organizations in general depends on the organization's ability to build a solid base of loyal customers, especially as these customers are often the source of attracting new customers through their opinions, recommendations and positive suggestions that are affected by new or potential customers, therefore, meeting customers' demands and increasing interaction and communication with customers will result in meeting their desires and consequently increase customer satisfaction. This is an important factor in forming customer loyalty to the organisation. (Hallowell Roger, 1996).

The concept of brand loyalty has become an important focus for marketing strategy research in recent years, and has been widely analyzed in the literature of marketing (e.g. Dick \& Basu, 1994). Customer loyalty means a customer would return or continue to use the same product or other products of the same organization, make business referrals, and intentionally or even unintentionally providing strong word-of-mouth references and publicity (Bowen and Shoemaker, 1998). Oliver (1999:34) has defined loyalty as "A deeply held psychological commitment to repurchase or repatronize a preferred product/service consistently in the future, thereby causing repetitive same-brand or same brand-set purchasing, despite situational influences and marketing efforts having the potential to cause switching behavior". Javalgi and Moberg (1997) defined loyalty according to behavioral, attitudinal, and choice perspectives. While behavioral perspective is based on the amount of purchases for a particular brand, attitudinal perspective incorporates consumer preferences and dispositions towards brands. According to Dimitriades, (2006) "loyal" are defined those customers who hold favourable attitudes toward an organization, recommend the organization to other consumers and exhibit repurchase behaviour.

Depending on these definitions many studies have considered that there are two dimensions to customer loyalty: behavioural and attitudinal (Akbar and Parvez, 2009; Chen, Chang and Lin, 2012; Day, 1969; Garcíaet al., 2005; Kandampully and Suhartanto, 2000; Perez et al., 2012).

The Behavioural Dimension refers to a customer's repeated purchase behaviour, indicating a preference for a specific brand over time(Kandampully and Suhartanto, 2000). Behavioral loyalty encompasses measurements of consistent, repetitious purchase behavior as an indicator of loyalty (Ehrenberg, Goodhardt, \& Barwise, 1990; Krishnamuthi \& Raj, 1991).

The Attitudinal Dimension refers to a customer's intention to repurchase and recommendation (Kandampully and Suhartanto, 
2000). This dimension means that a positive evaluation of the company is made and that an emotional link exists between the customer and the company that generates a real loyalty). Attitudinal brand loyalty consists of brand attitudes, attitudes toward intention to repurchase and brand commitment (Bennett \& Rundle-Thiele, 2002; Mellens, Dekimpe, \& Steenkamp, 1996).

\subsection{Mobile Marketing and Customer Loyalty}

The mobile phone is one of the of consumer's handful products to have gained global acceptance within a relatively short period (Barnes and Scornavacca, 2004). What distinguishes mobile marketing that it is done via different ways, and the most important services of mobile marketing are mobile advertising, mobile entertainment and mobile shopping. These elements stand out as the critical elements in mobile marketing (Süleyman, 2008).

The world's appetite for media and entertainment is seemingly insatiable. New channels and devices are enabling users to consume news, games, film, music TV, and books and more in an unprecedented manner in the web. The sheer volume of media choices has multiplied exponentially from the print and analogue media of the past. This growth poses an immense challenge to marketing because of entertainment services that can increase customer loyalty and add value for the customer. (Haghirian and Dickinger, 2010). The marketer can capture the attention and loyalty in a world saturated with media. For the traditional marketer mobile marketing can revamp revenue model, monetise content and drive ad sales, media companies stand out in a competitive landscape to meet consumers' demand for a relevant experience across channels. For every marketing challenge, the new world opens new opportunities for consumers themselves. Companies have at their disposal an unprecedented wealth of information, and the key is using that information for a competitive advantage across mobile marketing.

Mobile marketing is seen as a mean of achieving customer satisfaction and it is a future investment field. It also increases the relationship between the parties and helps to increase customers' communication and interaction between customers and organizations and thus increase the satisfaction of customers which achieve customer loyalty (Anjorin and Amarsana ,2012). mobile marketing is one of the active factors that affect awareness, composition and brand loyalty (Galeano et al., 2016). internal promotion has a direct effect on the online impulsive purchasing tendency and external promotion has an indirect effect on the online impulsive purchasing tendency by inducing positive reactions to online in-store promotion (Bucht and Gillberg, 2015). Gaughan and Lesely (2012), referred that using mobile phones in marketing enhance customer loyalty . Accordingly, the hypothesis of the study may be formulated as follows:

H1. There is a significant effect of mobile marketing on the customer loyalty in Jordan

More specifically:

H1a. There is a significant effect of Interactivity on the customer loyalty in Jordan

H1b. There is a significant effect of Personalization on the customer loyalty in Jordan

H1c. There is a significant effect of Localization on the customer loyalty in Jordan

H1c. There is a significant effect of Convenience on the customer loyalty in Jordan

\section{Study Model}

Based on the study hypotheses, the study model can be developed. The model illustrates the relationship between the independent variables and the deper '

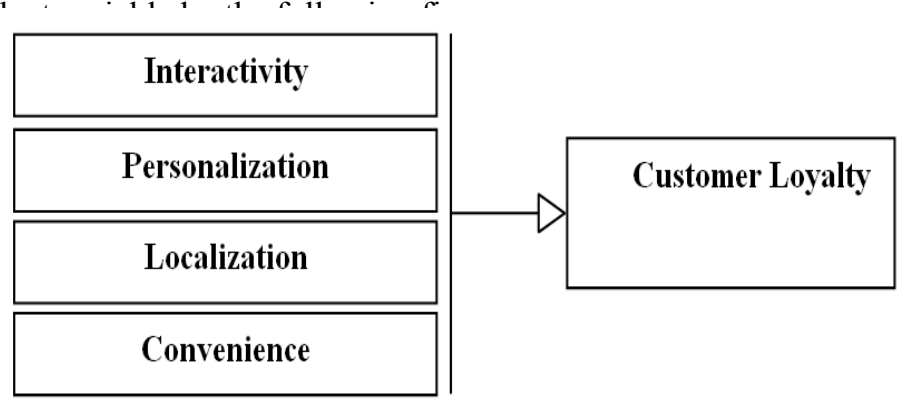

Figure 2. Theoretical Model 


\section{Methodology}

\subsection{Study Design}

The independent variable of the study included four dimensions of mobile marketing. These four dimensions are: (1) Inteactivity, (2) personalization, (3) Localization, (4) Convenience, adopted by (Smutkupt, et al., 2010; Holland, 2010; Bauer et al., 2005; Gaughan, 2017 (The dependent variable (customer loyalty) consisted of two dimensions: the attitudinal loyalty and the behavioral loyalty, each represented a measurement of customer loyalty adopted by) Akbar and Parvez, 2009; Chen and Lin, 2012; Day, 1969; Salmones et al., 2005; Kandampully and Suhartanto, 2000; Perez et al., 2012) .

\subsection{Study Tool}

The study tool consists of three parts: the first part deals with demographic information of the study sample, The second part deals with the dimensions of the independent variable (Mobile Marketing), Interactivity (Smutkuptet al., 2010; Holland, 2010; Bauer et al., 2005). Personalization) Smutkupt et al., 2010; Holland, 2010; Bauer et al.,2005; Efraim and David, 2002; Zeng et al., 2003; Michael and David, 2003). Localization) Smutkupt et al., 2010; Holland, 2010; Bauer et al., 2005; Efraim and David, 2002; Zeng et al., 2003; Michael and David, 2003). Convenience (Zeng and Yen2003; Efraim and David 2002; Michael and David 2003).

The third part measures the customer loyalty both attitudinal loyalty and behavioural loyalty. Previous studies were used to determine this variable.(Akbar and Parvez, 2009; Chen, Chang and Lin, 2012; Day, 1969; Salmones et al., 2005; Kandampully and Suhartanto, 2000; Perez et al., 2012).

\subsection{Study Population and Sample}

The study population was represented by all customer who using mobile marketing in Jordan, and who basically rely on it to get information while shopping as well as aware of its use, and this knew by asking them directly, on street and where customer gathering, such as Hypermarkets and Malls. a convenience sample was taken, A study sample of (500) customers who use mobile phone services taken. A (67) questionnaires were not retrieved, (30) questionnaires were not valid for analysis, and

\begin{tabular}{|l|l|l|c|}
\hline Variable & Categories & Repeat & Percentage \\
\hline Sex & Male & 283 & 70.2 \\
& Female & 120 & 29.8 \\
\hline \multirow{2}{*}{ Age } & Total & 403 & 100.0 \\
& Less Than 20 & 41 & 10.2 \\
& 20 Less Than 30 & 110 & 27.3 \\
& 30 Less Than40 & 208 & 51.6 \\
& 40 Less Than 50 & 34 & 8.4 \\
& 50 and Over & 10 & 2.5 \\
\hline \multirow{2}{*}{ Income } & Total & 403 & 100.0 \\
& Less than 500 & 10 & 2.5 \\
& 500 less than 1000 & 88 & 21.8 \\
& 1000 and over & 305 & 75.7 \\
\hline \multirow{2}{*}{ Educational level } & Total & 403 & 100.0 \\
& Diploma and less & 315 & 78.2 \\
& Bacholar & 78 & 19.4 \\
& Postgraduate & 10 & 2.5 \\
\hline & Total & 403 & 100.0 \\
\hline
\end{tabular}

Table 7. Sample Characteristics 
(403) questionnaires were valid for analysis. Table (7) shows the calculation of repeats and percentages of personal and functional variables.

Male makes (70.2\%), while (120) of the sample were female customers (29.8\%). With regard to age group, the largest group of the sample distribution was(30 to less than 40$)$ making $(51.6 \%)$, while the smallest group of the sample was (50 years and more) making $(2.5 \%)$.With regard to income the income group (1000 and above) making (75.7\%), while the smallest group was (less than 500) making (2.5\%). The largest percentage of educational level (78.2\%) belong to the educational level group (Diploma and less), while the smallest percentage of educational level $(2.5 \%)$ belong to the educational level group (postgraduate).

\subsection{Procedural Definitions}

Mobile Marketing: Multiple channels and online marketing techniques that focused on reaching a specific audience on their mobile phone using features of modern mobile technology regardless of the time and place.

Interactivity: The communication between the two parties in marketing, which achieve interaction between the marketer and the customer.

Personalization: The mobile phone is highly personal, rarely used by anyone except its owner and can store personal information and identity which later allows the marketer to use it to meet the customer needs

Localization: The ability to identify the geographical position of a mobile user by locating the mobile device.

Convenience: The state of being able to proceed with marketing via mobile phone with little effort or difficulty.

Customer loyalty: is the point at which a customer deals with a brand (or buys a particular item or a specific vendor) on an ongoing basis.

\subsection{Reliability and Validity of the Survey Instrument}

The survey instrument with 35 items was developed based on two variables

Mobile Marketing dimensions as independent variables with four dimensions; Inteactivity, (2) personalization, (3) Localization, (4) Convenience. Customer loyalty as dependent variables with two dimensions: attitudinal loyalty and the behavioral loyalty.

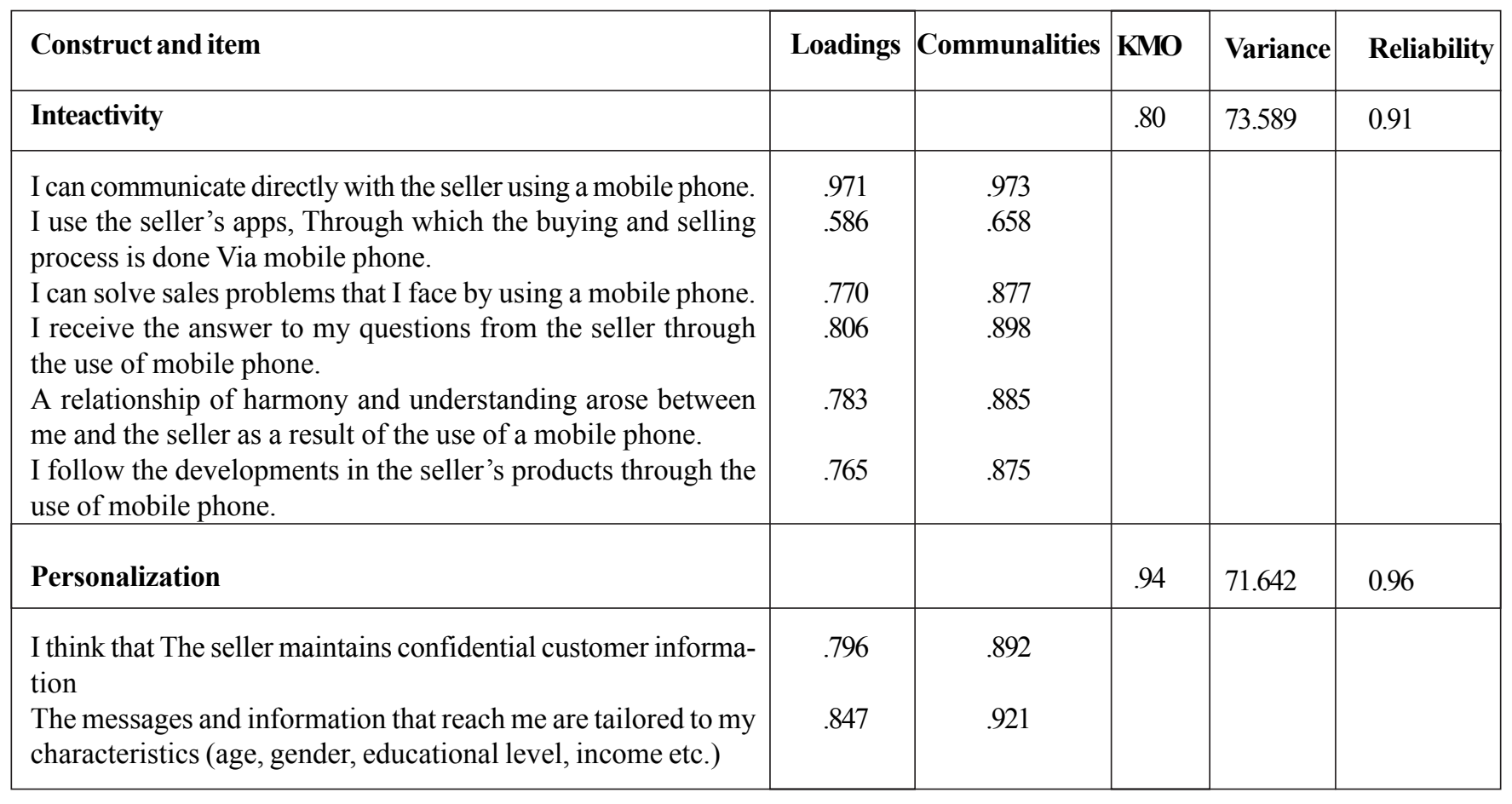

144 International Journal of Web Applications Volume 11 Number 4 December 2019 
I believe that existing laws and regulations protect my per sonal data while shopping on mobile phones.

I can keep my own information safe during the shopping process using my mobile phone.

I Choose products that commensurate with me and with my personal information using the mobile phone.

I can focus on specific products through mobile shopping. I share ads and offers that reach me with others via different means and tools available on mobile phones

I can determine with whom I share regarding advertising and information through my mobile phone.

I Receive Offers tailored to my particular interests through mobile shopping.

\begin{tabular}{|c|c|c|c|c|c|}
\hline Localization & & & .78 & $74 . .832$ & 0.88 \\
\hline $\begin{array}{l}\text { I can locate a product or seller via location-based services in a } \\
\text { mobile phone. }\end{array}$ & .775 & .880 & & & \\
\hline $\begin{array}{l}\text { I think that the ads that reach me on the mobile phone suit my } \\
\text { geographical location. }\end{array}$ & .774 & .880 & & & \\
\hline $\begin{array}{l}\text { I can get important information and offers from Seller closest to } \\
\text { where I am located via mobile phone. }\end{array}$ & .779 & .883 & & & \\
\hline $\begin{array}{l}\text { The marketer can Determine my current location so that he can } \\
\text { send information about the offers and products that suit me. }\end{array}$ & .665 & .816 & & & \\
\hline Convenience & & & .91 & 79.291 & 0.94 \\
\hline I think that using a mobile phone in shopping is the easiest way. & .755 & .869 & & & \\
\hline $\begin{array}{l}\text { The mobile phone allows me to access services and information } 7 / \\
24\end{array}$ & .793 & .890 & & & \\
\hline $\begin{array}{l}\text { I am satisfied with the services offered by the Sellers over the } \\
\text { mobile phone. }\end{array}$ & .811 & .900 & & & \\
\hline $\begin{array}{l}\text { The design of the mobile phone screen (colors, boxes, menus, } \\
\text { iconsetc.) is comfortable and efficient. }\end{array}$ & .821 & .906 & & & \\
\hline $\begin{array}{l}\text { I am acquainted with all the services and tools that a mobile phone } \\
\text { offers in shopping. }\end{array}$ & .755 & .869 & & & \\
\hline
\end{tabular}

Table 8. Factor analysis of Mobile Marketing dimensions

\begin{tabular}{|c|c|c|c|c|c|}
\hline Construct and item & Loadings & Communalities & KMO & Variance & Reliability \\
\hline \multicolumn{6}{|l|}{ Attitudinal loyalty } \\
\hline $\begin{array}{l}\text { I find that the availability of many services in the mobile phone } \\
\text { makes it one of the most important means of marketing. }\end{array}$ & 0.662 & 0.697 & .711 & 68.554 & 0.89 \\
\hline $\begin{array}{l}\text { I always find that the ads and offers that Reach me over Mobile } \\
\text { Phone useful. }\end{array}$ & 0.711 & 0.752 & & & \\
\hline $\begin{array}{l}\text { The services provided by the Sellers through the mobile phone } \\
\text { are helpful and have achieved my full expectations. }\end{array}$ & 0.673 & 0.699 & & & \\
\hline $\begin{array}{l}\text { I find that my choice to get the service by mobile phone from the } \\
\text { wise decisions I have taken. }\end{array}$ & 0.643 & 0.685 & & & \\
\hline $\begin{array}{l}\text { I feel comfortable in all my shopping experiences through the } \\
\text { mobile phone. }\end{array}$ & 0.734 & 0.788 & & & \\
\hline
\end{tabular}




\begin{tabular}{|c|c|c|c|c|c|}
\hline Behavioral loyalty & & & & & \\
\hline $\begin{array}{l}\text { I Am interested in publishing information and offers from sell- } \\
\text { ers which I deal with them to friends and family via mobile } \\
\text { phone. }\end{array}$ & 0.725 & 0.754 & .772 & 71.234 & 0.88 \\
\hline $\begin{array}{l}\text { Shopping via Mobile phone is an important factor in identify- } \\
\text { ing the Seller and stores that I am buying from them. }\end{array}$ & 0.689 & 0.724 & & & \\
\hline $\begin{array}{l}\text { When I make a purchase or pay by mobile phone, I prefer to } \\
\text { deal with the Sellers which I dealt with them previously through } \\
\text { this means. }\end{array}$ & 0.642 & 0.668 & & & \\
\hline $\begin{array}{l}\text { The offers that reach me via mobile phone check value for me } \\
\text { by getting the lowest price. }\end{array}$ & 0.667 & 0.697 & & & \\
\hline $\begin{array}{l}\text { I prefer it if the sellers and stores who I deal with, adopt the } \\
\text { latest technologies in mobile marketing }\end{array}$ & 0.716 & 0.739 & & & \\
\hline
\end{tabular}

Table 9. Factor analysis of Customer loyalty dimensions

The instrument were evaluated for reliability and validity. Reliability refers to the instrument's ability to provide consistent results in repeated uses (Gatewood \& Field, 1990). Validity refers to the degree to which the instrument measures the concept the researcher wants to measure (Bagozzi \& Phillips, 1982).

Factor analysis and reliability analysis were used in order to determine the data reliability for the Mobile Marketing and Customer loyalty. A within factor, factor analysis was performed to assess convergent validity. The results of the factor analysis and reliability tests are presented in Table (8) and Table (9). All individual loadings were above the minimum of 0.5 recommended by Hair et al. (1998). For exploratory research, a Chronbach $\alpha$ greater than 0.70 is generally considerate reliable (Nunnally, 1978). Chronbach $\alpha$ statistics for the study contracts are shown in Table (5) and Table (6). Thus it can be concluded that the measures used in this study are valid and reliable. Kaiser-Meyer-Olkin has been used as Pre-analysis testing for the suitability of the entire sample for factor analysis as recommended by Comrey (1978), the value of The Kaiser-Meyer-Olkin measure was used to assess the suitability of the sample for each unifactorial determination. The KMO values found (see Table 8, and 9) are generally considered acceptable (Kim and Mueller, 1978). All factors in each unifactorial test accounted for more than 58.6 per cent of the variance of the respective variable sets. This suggests that only a small amount of the total variance for each group of variables is associated with causes other than the factor itself.

\subsection{Descriptive Statistics Analysis}

Table (10) indicates that the customers who using mobile marketing in Jordan evaluate Inteactivity (with the highest mean scores, i.e. $\mathrm{M}=3.38, \mathrm{SD}=0.78$ ) to be the most dominant of mobile marketing dimension and evident to a considerable extent, followed by Localization $(\mathrm{M}=3.19, \mathrm{SD}=0.84)$, Convenience $(\mathrm{M}=3.15, \mathrm{SD}=0.95)$, and personalization (with the lowest mean scores $\mathrm{M}=3.14$, $\mathrm{SD}=0.68$ ). With regard to Customer loyalty, customers who using mobile marketing evaluate their behavioral loyalty (with the highest mean scores, i.e. $\mathrm{M}=3.68, \mathrm{SD}=0.67)$ to be the most dominant customer loyalty dimension and evident to a considerable extent, and attitudinal loyalty (with the lowest mean scores $\mathrm{M}=3.42, \mathrm{SD}=0.91$ ).

\begin{tabular}{|l|c|c|}
\hline Dimension & Mean & Standard deviation \\
\hline Mobile Marketing dimensions & 3.19 & \\
Inteactivity & 3.38 & 0.78 \\
personalization & 3.14 & 0.68 \\
Localization & 3.19 & 0.84 \\
Convenience & 3.15 & 0.95 \\
Customer loyalty & 3.55 & \\
attitudinal loyalty & 3.42 & 0.91 \\
behavioral loyalty & 3.68 & 0.67 \\
\hline
\end{tabular}

Table 10. Descriptive analysis of Mobile Marketing and Customer loyalty 


\begin{tabular}{|l|l|l|l|c|}
\hline Field & Number & dimension & $\begin{array}{l}\text { Value of One-Sample } \\
\text { Kolmogorov-Smirnov Test }\end{array}$ & Statistical significance \\
\hline \multirow{2}{*}{ Mobile Marketing } & 1 & Interactivity & 1.06 & 0.29 \\
& 3 & Personalization & 1.05 & 0.06 \\
& 4 & Localization & 1.06 & 0.07 \\
& 6 & Convenience & 1.04 & 0.07 \\
\hline Customer loyalty & 1 & Attitudinal loyalty & 1.01 & 0.09 \\
& 2 & Behavioral loyalty & 1.09 & 0.08 \\
\hline
\end{tabular}

Table 11. One-Sample Kolmogorov-Smirnov Test for each dimension of the dependent and independent variables

\subsection{Normality Distribution Test}

One-Sample Kolmogorov-Smirnov Test was applied for each dimension of the independent and dependent variables. Table (11). Table (11) shows The statistical significance values from the) One-Sample Kolmogorov-Smirnov Test (The data indicated the normal distribution trace and the theory of central tendency, which stated that the sample size is greater than 30. It has a mean $(\mu)$ and a variation) $\sigma^{2}$. The sampling distribution of the mean is close to normal distribution.

\section{Test of Hypothesis}

Table (12) shows the values of the variance inflation factor test of the independent variable dimensions ranges between (1.99 3.26). The Tolerance value for each dimension of independent variable was higher than $(0.05)$ where the value ranged between $(0$. 5 - 0.31 ), thus, there is no problem with a high correlation between the dimensions of the independent variable.

Multiple regression analysis was employed to test the hypotheses. It is a useful technique that can be used to analyze the relationship between a single dependent variable and several independent variables (Hair et al., 1998). In this model, Organizational Customer loyalty acts as the dependent variable and Mobile Marketing dimensions, as the independent variables. From the result as shown in Table (12), the regression model was statistically significant $(\mathrm{F}=73.305$; $\operatorname{AdjR} 2=.519 ; \mathrm{P}=.000)$. The AdjR2 is 0.519, which means that 51.9 per cent of the variation in Customer loyalty can be explained by Inteactivity, personalization, Localization, and Convenience. The proposed model was adequate as the F-statistic $=73.305$ was significant at the $5 \%$ level $(p<$ 0.05). This indicates that the overall model was reasonable fit and there was a statistically significant association between Mobile Marketing and Customer loyalty.

Table (12) also shows that Inteactivity $(\beta=0.098, \mathrm{p}<0.05)$, personalization $(\beta=0.231, p<0.05)$, and Convenience $(\beta=0.461, p<$ 0.05 ) had a significant and positive effect on Customer loyalty. This provides evidence to support H1a, H1b, and H1D, while,

\begin{tabular}{|c|c|c|c|c|c|c|c|c|}
\hline \multirow{2}{*}{\multicolumn{2}{|c|}{ Model }} & \multicolumn{2}{|c|}{$\begin{array}{l}\text { Unstandardized } \\
\text { coefficients }\end{array}$} & \multirow{2}{*}{$\begin{array}{l}\begin{array}{l}\text { Standardized } \\
\text { coefficients }\end{array} \\
\text { B } \\
\end{array}$} & \multirow{3}{*}{$\begin{array}{c}\mathbf{T} \\
11.913\end{array}$} & \multirow{3}{*}{$\begin{array}{l}\text { Sig. } \\
.000\end{array}$} & \multicolumn{2}{|c|}{ Collinearity Statistics } \\
\hline & & B & Std. error & & & & Tolerance & VIF \\
\hline \multirow[t]{5}{*}{1} & Constant & 1.594 & .134 & & & & & \\
\hline & Inteactivity & .089 & .044 & .098 & 2.019 & .044 & 0.50 & 1.99 \\
\hline & personalization & .239 & .064 & .231 & 3.714 & .000 & 0.31 & 3.25 \\
\hline & Localization & .078 & .042 & .094 & 1.864 & .063 & 0.47 & 2.13 \\
\hline & Convenience & .340 & .046 & .461 & 7.378 & .000 & 0.31 & 3.26 \\
\hline
\end{tabular}

Notes: $R 2=.526$; Adj. $\mathrm{R} 2=.519$, Sig. $\mathrm{F}=0.000$, F-value $=73.305$, dependent variable, Customer loyaltyp $<0.05$

Table 12. Regression Summary of Mobile Marketing and Customer loyalty (N=403) 
Localization $(\beta=0.094, p<0.05)$ had insignificant effect on Customer loyalty. Based on the $\beta$ values Convenience has the highest impact on Customer loyalty followed by personalization, finally Inteactivity.

\section{Discussion}

The study aimed at identifying the impact of mobile marketing on customer loyalty in Jordan through the investment of mobile marketing and employs it to serve the needs of customers, which is reflected on the achievement of loyalty of customer in the face of this competitive sector. This study is designed To be an addition to the literature that are related to mobile marketing and to provide information that helps the marketing managers and decision-makers for keep ahead of technological developments in an environment of constant change.

Based on the study results, it is clear that Mobile device adoption rates are increasing at an unbelievable rate indicating the importance of tailoring marketing efforts. People spend more time on mobile devices, so mobile marketing and mobile commerce Go Hand-In-Hand because mobile technology gives customers chance to shop and compare while they walk down the store. Marketers took the opportunity and put their marketing messages into the hands of their consumers, and mobile allowed marketers to reach much wider customers by doing so. In addition, Interactivity feature enables the customer obtaining answers on his questions and receive complaints and access to after-sales service also. The existing ways for Interactivity, are Websites, e-mail, or face-to-face Interactivity, may reduce the importance of mobile interactivity, as well as substantive matters and technical issues required by the use of mobile phone.

Because of mobile features, marketers can personalize the messages based on the consumer preferences, age, sex, local time .. etc, which makes message less intrusive than mobile phone calls or other ways of marketing, also customers can read messages or surfing advertisements at their leisure time and choose when to respond, they can see the right content for them through the use of the marketer their personal information. Stability and security issues might also keep customers from using a mobile phone to register for information or using their real information.

Localization feature through using mobile, is a new tool for marketing but the high-speed wireless network technologies, such as GPS, attract more customers increasingly rely on Localization feature in their phones, also web mapping services like Google Maps Contributed to the development of this dimension and gave it importance to the consumer, but the marketer needs to combine the right moment, place and relevancy of the message for sending marketing content to benefit the most of this new medium and that what is make it a bit difficult.Also customer believed that mobile marketing increases their shopping efficiency by reducing their search time for products and services. Mobile phones are becoming increasingly popular tools for communication across all demographics.

They are lighter, smaller, cheaper and more portable than other devices like tablets and laptops, this suggests that more people are engaging in mobile marketing for the convenience and the efficiency of conducting routine tasks than for the discounts or shopping offers, But still some things like, frequent mobile phone charging, lack of network availability and lack of internet, and that there are easier ways in some aspects, some examples keying in text messages takes time, registration via web forms, by contrast, is easier thanks to a large computer keyboard, these are things that count out of the passive use of mobile phone marketing. customer's purchasing behaviour is influenced by mobile marketing dimensions and constitutes a major factor of high degree of repeated customer interaction within the same sellers. mobile marketing primarily affects the behavior that is reflected in the customer's ideas about the market or seller and that he is less interested in spreading these ideas between his environment and society .

The study results showed that there is an impact of Interactivity on the customer loyalty. This indicates that marketers and sellers are responding quickly to customer requests and inquiries which are reflected in customer satisfaction and increase loyalty. It also Demonstrates the sellers and marketers success in Jordan in solving and minimizing customer problems over mobile. The study also showed an impact of Personalization on customer loyalty, this impact is achieved through the province of sellers and marketers on the personal information about customers and their non-diversion, which helps to increase customer orientation towards more mobile phone services, as this reduces the fear of dealing with mobile phone e-services, so customers feel reassured and satisfied that there is confidence in the seller and marketer which increases customer loyalty.

The study results showed that there is an impact of Localization on the customer loyalty, marketers can now leverage real-time data to better target consumers based on where they go, effectively measure how mobile phone ads drive foot traffic into market

148 International Journal of Web Applications Volume 11 Number 4 December 2019


and even connect the consumer journey from ad exposure to market visit to purchase data, furthermore, marketers and sellers are capable to target customers within a given geographical area by changing the marketer marketing messages based on geographically targeted customers by knowing where their consumers are and how they usually behave, and they had been able to tap into their habits and also encourage them with offers and messages that make sense to them, which relate to their location by using real-time location data supplied by the mobile provider, this, they can display mobile ads and information to a possible customer who is close to a particular location, but poor knowledge of this technology by customers, especially older people, has affected their effectiveness in marketing, and it is not used effectively and appropriately by marketers.

The results of the study showed that there is an impact of Convenience on the customer loyalty. This means that the ease of use of mobile phones in shopping contributes to the loyalty of customers through the ease of portability and screen clarity and rapid loading and switching from one service to another easily, which help customers to complete their transactions easily without fatigue, the customer gets comfortable and pleased and the customer just go about using more mobile phone service. The speed of access to the service and ease of use by the customer using a few steps in the shortest possible time, reflecting the ease of use wherever the customer is, and whenever the service is fast and easy the customer increased uptake of marketing services because customers tend to use it in their nature.

\section{Managerial Implications}

Based on the study findings, the researchers recommend marketers and decision-makers to use specialized experts in the field of mobile content design, in particular, to create a consistent and unified view of the customer when designing mobile ads or information content and experience, to support their attractiveness for customers, and to share the knowledge base between different mobile marketing channels to enhances and protects their credibility by ensuring the right information is available, regardless of channel, to put customers in control of their experience, giving them access to the right answers, wherever they are.

Marketers and managers should benefit from the experiences of developed countries in the field of customer information protection and monitoring software to enhance the existing software implemented by the marketers, and to establish a specialized department for whom are specialized in solving problems of customers through the means of interaction in the mobile phone that operates 24 hours even on holidays, and subject them to training courses in that area to accelerate their response to customers and save time for them.

\section{Limitations and Direction for Future Research}

The study suffers from a number or shortcomings that must be considered and possibly addressed in future research despite its contribution to some interesting findings. First, based on result in this study, we propose that this study replicated in other countries, or making a comparative study between two or more countries. Second, research can handle more variables characteristics of mobile marketing as industry background to examine its impact on customer loyalty. Third, the sample size was restricted to 403 due to costs and time reasons. Thus, the extent to which the results can be generalized to the whole population is questionable so we propose a research with large sample may be investigated to make the possibility of generalizing the results. Fourth, there are several of variables that may enhance customer loyalty, and each variable has its respective coverage. Thus, the researchers doing follow-up research should review other literature to select different variables and dimensions and provide a more integrated investigation.

\section{References}

[1] Aaker, D. (1995). Dimensions of brand personality. Journal of Marketing Research, 36(3), 10-206. a. acceptance. International Journal of Mobile Communications, 2(2) 128-39.

[2] Al-alak, Alnawas. (2010). Evaluating the effect of marketing activities on relationship quality in the banking sector. International Journal of Marketing Studies, 21(1) 78-91.

[3] Al-qatan, S. (2011). Theoretic discussion of Tourism M-commerce. Research Journal of Applied Sciences, 6(6) 366-372.

[4] Balasubramanian, S., Peterson, R. A., Jarvenpaa, S. L. (2002). Exploring the Implications of M-Commerce for Markets and Marketing. Journal of the Academy of Marketing Science, 30 (4) 348-361.

[5] Barnes, S. J., Scornavacca, E. (2004). Mobile marketing: the role of permission. 
[6] Bauer, H., Reichardt, T., Barnes, J., Neumann, M. (2005). Driving consumer acceptance of mobile marketing: A theoretical framework and empirical study. Journal of Electronic Commerce Research, 6(3) 181-192.

[7] Bruner, G. C., Kumar, A. (2007). Attitude toward location-based advertising. Journal of Interactive Advertising, 7(2) 3-15.

[8] Bucht, E., Gillberg, R. (2015). Mobile Marketing and its Effects on the Online Impulsive Purchasing Tendency, Unpublished Master Dissertation, Luleå University of Technology, Luleå, Sweden.

[9]Chen, F. Y., Chang, Y. H., Lin, Y. H. (2012). Customer perceptions of airline social responsibility and its effect on loyalty. Journal of Air Transport Management, 20, 49-51.

[10]Childers, T. L., Carr, J., Carson, S. (2001). Hedonic and Utilitarian Motivations for Online Retail Shopping Behavior, Journal of Retailing,77(1) 511-535.

[11] Clarke, I. (2001). Emerging value propositions for m-commerce. Journal of Business Strategies, 18(2) 133-148.

[12] Conceptual model of SMS marketing, International Conference on System Sciences, 37, Hawaii 5-8 Jan. 2004, 471-480.

[13] Coyles, S., Gokey, T. C. (2005). Customer retention are not enough. Journal of Consumer Marketing, 22(2), 101-105.

[14] Day, G. (1969). A two-dimensional concept of brand loyalty. Journal of Advertising Research, 9(3), 29-35.

[15] Dickinger, A., Murphy, J. (2005). Diffusion and success factors of mobile marketing. Electronic Commerce Research and Applications, 4(2) 159-173.

[16] Dickinger, A., Haghirian, P., Murphy, J., Scharl, A. (2004). An investigation and Dowling Grahame (2002), Customer Relationship Management, EBSCO Publishing California

[17] Efraim, T. (2012). Electronic Commerce A Managerial and Social Networks Perspective, $8^{\text {th }}$ edition,SpringerCham: Heidelberg.

[18] Fiegerman, Seth. (2011). 7 Gadgets That Won't Be Around In 2020. Available: http://shopping.yahoo.com/articles/ yshoppingarticles/717/7-gadgets-that-wont-be-around-in- [27 October 2017 ]

[19] Fortin, D. (1997). The impact of interactivity on advertising effectiveness in the new media, Unpublished Master Dissertation, College of Business Administration, Kingston, RI,Island. from 45 popular cases for campaign design. SJMM, 5(1), 175-192

[20] Galeano, M., Zavareh, M., Bahrami, E. (2016). Effect of Mobile Marketing on Customer oriented Brand Equity in Insurance Industry. International Journal of Management, Accounting and Economics, 3( 3) 185 - 201.

[21] Gana, M., Koce, H. (2016). Mobile Marketing: The Influence of Trust and Privacy Concerns on Consumers' Purchase Intention. International Journal of Marketing Studies, 8(2) 121-127.

[22] Gao, T., Rohm, J., Sultan, F., Pagani, M. (2012). Brand in the hand: A cross-market investigation of consumer acceptance of mobile marketing. Business horizon, (2012) 55, 485-493.

[23] Gao, T., Rohm, J., Sultan, F., and Pagani, M. (2013). Consumers untethered: A three-market empirical study of consumers' mobile marketing acceptance. Journal of Business Research, 66(12) 2536-2544

[24] Gao, Q., Rau, P., Salvendy, G. (2009). Perception of interactivity: effects of four key variables in mobile advertising. International Journal of Human-Computer Interaction, 25(6) 479-505.

[25] García, D., Salmones, M. M., Herrero, A., Rodríguez, I. (2005). Influence of corporate social responsibility on loyalty and valuation of services. Journal of Business Ethics, 61(4) 369-385.

[26] Gaughan, Lesely. (2012). Mobile marketing a tool for building customer loyalty, Unpublished Masters Dissertation, Letterkenny Institute of Technology, County Donegal, Ireland.

[27] Haghirian, P., Inoue, A. (2007). An advanced model of consumer attitudes toward advertising on the mobile internet. International Journal of MobileCommunications, 5(1) 48-67.

[28] Haig, Matt. (2002). Mobile marketing: the message revolution, London: Kogan Page Ltd.

[29] Hallowell, R. (1996). The relationships of customer satisfaction, customer loyalty, and profitability: an empirical study. International Journal of Service Industry Management, 7(4) 27-42,

[30] Heinonen, K., Strandvik, T. (2007). Consumers responsiveness to mobile marketing. International Journal of Mobile Communications, 5(6) 603-617. 
[31] Holland, J. (2010). The Role of Mobile Marketing Communications in the IMC Strategy. Innovative Marketing, 6(2), 23.

[32] Hsiao, W., Wu, S., Wu, I. (2015). Analyzing Consumer Loyalty of Mobile Advertising: A View of Involvement, Content, and Interactivity and the Mediator of Advertising Value. The Ninth International Conference on Mobile Ubiquitous Computing, Systems, Services and Technologies, Nice, France, July 20 - 25, 2015, 44-49.

[33] Huang, R. Y., Symonds, J. (2009). Mobile marketing evolution: A Systematic literature review on multi-channel communication and multi-characteristics campaign. In: Proceedings of the IEEE Enterprise Distributed Object Computing Conference Workshops and Short Papers, Auckland, New Zealand, 1-4 sept, 2009, 157-165.

[34] Janssens, Camille. (2012). Brand awareness and brand attitude in Location Based Advertisements Related to persuasiveness and consumer acceptance. Unpublished Masters Dissertation Dissertation, Tilburg University, Tilburg. Netherlands.

[35] Junglas, I. A., Watson, R. T. (2003). U-commerce: a conceptual extension of e-commerce and m-commerce. Proceedings of the twenty-fourth international conference on information systems, Seattle, Washington, USA,15-17 December 2003, 667-677.

[36] Kandampully, J., Suhartanto, D. (2000). Customer loyalty in the hotel industry: the role of customer satisfaction and image. International Journal of Contemporary Hospitality Management, 12 (6) 346-351.

[37] Kaplan, A. M. (2012). If you love something, let it go mobile: Mobile marketing and Mobile social media 4x4. Business Horizons, 55(2) 129-139.

[38] Kelleher, T. (2009). Conversational voice, communicated commitment, and public relations outcomes in interactive online communication. Journal of Communication, 59(1) 172-188.

[39] Keller, K. L. (2001). Mastering the Marketing Communications Mix: Micro and Macro Perspectives on Integrated Marketing Communication Programs. Journal of Marketing Management, 17(1) 819-847.

[40] Klein, L. R. (2003). Creating virtual product experiences: The role of telepresence. Journal of Interactive Marketing, 17(1) $41-55$.

[41] Kotler, P., Keller, K. L. (2009). Marketing Management (13 ed), New Delhi: Prentice Hall of India, 213 -225.

[42] Laudon, K., Laudon, J. (2014). Management Information Systems Managing the Digital Firm, England, Harlow Edinburgh Gate,13ed: Pearson Education Limited.

[43] Liao, K.C., Lee, W. H. (2010). A Novel User Authentication Scheme Based on QR-Code. Journal of Networks, 5(8) 937-941.

[44] Looney, A., Jessup, L., Valacich, J. (2004). Merging Business Models For Mobile Brokerage Services. Communications of The Acm, 74(6) 71-77.

[45] Michael, S., David, S. A. (2003). Model for small business new technology adoption: the case of mobile commerce. In: Proceedings of 2003 ASBE Conference, Houston, Texas, Mar. 5-8, 2003.

[46] Mirbagheri, S., Hejazinia, M. (2010). Mobile marketing communication: Learning.

[47] Mort, G. S., Drennan, J. (2002). Mobile digital technology: emerging issues for marketing. Journal of Database Management, $10(1) 9-23$.

48] Perez, A., García DelosSalmones, M. M., Rodríguez del Bosque, I. (2012). The effect of corporate associations on consumer behaviour. European Journal of Marketing, 47(1) 218-238.

[49] Pihlström, Minna. (2008). Perceived value of mobile service use and its consequences. Unpublished Master Dissertation, Swedish School of Economics and Business Administration, Finland, Helsinki.

[50] Pousttchi, K., Wiedeman, D. ( 2010 ). Handbook of research On Mobile Marketing Management, New York, Hershey: IGI Global.

[51] Raney, A., Arpan, L., Pashupati, K., Brill, D. (2003). At the movies, on the web: an investigation of the effects of entertaining and interactive web content on site and brand evaluations. Journal of Interactive Advertising, 17(4) 38-53.

[52] Richardson, Neil. (2010). Quick start guide to mobile marketing create a dynamic campaign and improve your competitive advantage. London: Kogen Page Ltd. 
[53] Schierholz, R., Kolbe, L. M., Brenner, W. (2007). Mobilizing customer relationship management: a journey from strategy to system design. Business Process Management Journal, 13 (6), 830-852.

[54] Shankar, V., Balasubramanian, S. (2009). Mobile marketing: A synthesis and prognosis, Journal of Interactive Marketing, $23(2), 118-129$.

[55] Smutkupt, P. Krairit, D. and Esichaikul, V. (2010). Mobile marketing: implications for marketing strategies. International Journal of Mobile Marketing, 5(2), 128.

[56] Suleyman, B. (2008). Consumers' Attitudes Towards Mobile Marketing and Mobile Commerce in Consumer Markets. Ege Academic Review, 8(1),15-32.

[57] Waele, Ruy. (2010). Mobile Trends 2020. Retrieved, 27 October, 2017, from http://www.slideshare.net/rudydw/mobile-trends2020.

[58] Wang, Y. (2013). More People Have Cell Phones Than Toilets, U.N. Study Shows., Retrieved, 2 Oct 2017, from: http:// newsfeed.time.com/2013/03/25/

[59] Wells, W., Moriarty, S., Burnett, J. (2006). Advertising: Principles and Practices, $\left(7^{\text {th }}\right.$ ed), New Delhi: Prentice Hall of India.

[60] Welsch, Harold. (2004). Entrepreneurship the way ahead, New York 35Street: Routledge.

[61] Zeng, E. Y., Yen, D. C., Hwang, H. G., Huang, S. M. (2003). Mobile Commerce: The Convergence of E-Commerce and Wireless Technology. International Journal of Services Technology and Management, 4(3). 